\title{
The History and Function of Sisterhood in Turkey: Bacıyan-ı Rum Organization in Medieval Era
}

\author{
Sefa Bulut ${ }^{1}$ \\ 1 İbn Haldun Üniversitesi, Istanbul- \\ Turkey
}

Corresponding Author: Sefa Bulut, email: sefa.bulut@ihu.edu.tr, Ordu cad. F-05 Blok No 3, 34480

Bașakșehir, Turkey

\begin{abstract}
Baclyan-l Rum (Anatolian Sisters Organization) is known as the world's first women's organization in history, but very few pieces of literature exist about this medieval organization. Thus, the aim was to reach up to all available historical documents about the topic and systematically analyze the nature and function of such an organization in the medieval era. Preliminary findings show that no written documents existed in English nor other languages except the Turkish language. It was also observed that this topic has emerged as an exciting area for many disciplines in recent times, leading to a sudden development of recent write-ups on such a topic. Therefore, this paper aims to introduce and explore the historical antecedent and functions of Baciyan-l Rum Organization to readers and other professionals interested in history, ethics, women, and gender studies. Kinds of literature were reviewed across history, economics, politics, travelogues, art, sociology, and anthropology to provide an extensive and detailed understanding of such a remarkable phenomenal women organization that existed in the Islamic world of the Medieval Era in Anatolia, Turkey.
\end{abstract}

Keywords: AkhiWomen; Bacıyan-ı Rum; women organization; history of women; futuwwa

Abstrak: Bacıyan-ı Rum (Organisasi Suster Anatolia) dikenal sebagai organisasi wanita pertama di dunia dalam sejarah, tetapi sangat sedikit literatur tentang organisasi abad pertengahan ini. Jadi, tujuannya adalah untuk menjangkau semua dokumen sejarah yang tersedia tentang topik tersebut dan secara sistematis menganalisis sifat dan fungsi organisasi semacam itu di era abad pertengahan. Temuan awal menunjukkan bahwa tidak ada dokumen tertulis dalam bahasa Inggris atau bahasa lain kecuali bahasa Turki. Juga diamati bahwa topik ini telah muncul sebagai bidang yang menarik bagi banyak disiplin ilmu belakangan ini, yang mengarah pada perkembangan mendadak dari tulisan baru-baru ini tentang topik semacam itu. Oleh karena itu, artikel ini bertujuan untuk memperkenalkan dan mengeksplorasi anteseden sejarah dan fungsi Organisasi Bacıyan-ı Rum kepada pembaca dan profesional lain yang tertarik dalam studi sejarah, etika, wanita, dan gender. Berbagai literatur ditinjau dari segi sejarah, ekonomi, politik, catatan perjalanan, seni, sosiologi, dan antropologi untuk memberikan pemahaman yang luas dan terperinci tentang organisasi wanita fenomenal yang luar biasa yang ada di dunia Islam pada Abad Pertengahan di Anatolia, Turki.

Kata Kunci: Akhi Women; Bacıyan-ı Rum; organisasi perempuan; sejarah perempuan; persaudaraan 


\section{A. Introduction}

Across all human history, women have always been considered subservient and submissive to men. At the same time, others have either been ignored or neglected for many different reasons. History has also reported notorious events that targeted women, either as victims of circumstances or victims persecuted for trivial reasons and false accusations. The Medieval era, among others, is a specific period that was dominated by such happenings. Despite this, women were equally valued and considered as complementing and completing a man, for they have equal rights and status to men in the Islamic jurisdiction. This was typically true among the nomadic Turkish tribes because they lived and traveled together with their families to search for more animal feeds for their animals. This paper aims to investigate historical documents and dig out new information that is primarily unknown, unheard of, or rarely seen in our professional readings.

Baclyan- Rum Organization emerged during the Anatolian Seljuk's period in the 13 th century ${ }^{1}$ to organize and develop women. However, it is not easy to trace exactly when and its founders, this organization and its philosophy can be traced back to the Turkish tradition in Central Asia in terms of its cultural foundation. ${ }^{2}$ Among the Turkmen communities coming from Central Asia at the time, there were already elements of Akhism in their social and cultural life. These Akhism elements included economic and social solidarity, valiant, generosity, and politicized movements that are very similar to the ideas of sufism and futuwwa (fraternity, brotherhood) in Islam. Therefore, such attributes or futuwwa as a fraternity and brotherhood brought the result to them as people's efforts were leveraged, leading to it been institutionalized very quickly among the Anatolian Turks. Historians and folklorists credit the beginning and institutionalization of Akhism to Akhi Evran due to his most remarkable and selfless contribution. ${ }^{3}$

Besides traditionally published books and journal periodicals, mostly electronic search engines such as Sociological Abstracts, Antopolgical Abstracts,

\footnotetext{
${ }^{1}$ Sefa Bulut, "Women's Social Status and Prestige in Asia Minor during Medieval Era," Sociology Insights 3, no. 1 (2019): 1-2.

2Selahattin Döğüş, "Kadın Alplardan Bacıyanı-ı Rum’a (Anadolu Baclları Teşkilat); Türklerde Kadının Siyasi ve Sosyal Mevkii," Kahramanmaraş Sütçü İmam Üniversitesi Sosyal Bilimler Dergisi 12, no. 1 (2015): 127-50.

3Ziya Kazıcı, “Esnaf Teșkilat Ahilik,” Diyanet Dergisi 17, no. 3 (1978): 250-56.
} 
Eric, Psych Info, Psych List, ProQuest were used with the key terms "akhi women," "Bacıyan-ı Rum," and "historical women organizations" without any time restrictions to search for relevant documents and write-ups both in Turkish and English languages. Besides digital sources, some traditional published books and periodicals were also utilized in the literature search. It was not put no time limitations of the searching resources. At first, it was attempted to search sociological journals, gender studies, and historical periodicals, but it was relaxed that the topic under the investigation has a vast area of interest. Therefore, it limited our search for sociological or historical journals and publications and tried to use fundamental concepts in searching and locating relevant sources. Therefore, we find some new publications in theology, business, tourism, travelogues, public administrations, archeology, y, and other interdisciplinary journals. It appears that Akhi Man organizations have been extensively researched, and many publications appeared in professional journals.

On the other hand, Akhi Women, "Akhi Sisterhood," which is a parallel and complementing structure of the organization, has been for a long time ignored and does not draw researchers' attention. This can be because historians and academicians have been a male gender or only focused on men's history. History is done and written by men. Similarly, the chamber of commerce or commercial activities has been running by males so that women's contributions to the society and economy have been ignored for a long time. However, especially in recent years, some new publications, done mainly by female academicians, started to show some interest in women's history, particularly women in the medieval age. Those new publications were also beneficial for this paper.

Twenty-four written sources were identified directly or indirectly related to Akhi Women Organizations. Among them were 12 journal periodicals; of them, there were only 4 English articles, two of them belong to this article's author, ten books, which were all written in Turkish languages, and there were two conference proceedings in Turkish. Asit was stated early on, those publications come out in very recent years, and English literature is very scary, and there is almost nothing is written in English about Akhi sisterhood society.

Once we gathered information about different aspects of Akhi women's lives, we extracted the most crucial part of these lines. We got them together to organize a consistent and comprehensive literature review. After that, we 
provided some subsections of the paper. Since it is a literature review article, it was hard to follow the article's empiric writing method. It was intended to write an inclusive and informative text to stimulate more cultural curiosity and provide available information to the reader. It can also initiate some scientific stimulation; in other words, they can also start doing similar research in their cultural contexts.

\section{B. The History and Function of Bacıyan-ı Rum Organization}

The origin and formation of Futuwwa originated from Khorasan and migrated to Anatolia. The sisters within the Bacıyan-ı Rum Organization were influenced by the Sufi teaching and Akhism act of Haji Bektash Veli from Khorasan to Anatolia. In outlining Akhi Evran (1171-1261) contributions to the course of Akhism and Futuwwa, Haji Bektash in his work "Vilayetname" stated that "he came from Denizli to Konya, then to Kayseri, and then to Gülşehir" and further defined him as a person of Futuwwa whose origin was unknown and a saint of the invisible realm with many miracles. These attributes reflect the mutual admiration and respect between these two Akhism and Futuwwa personalities. $^{4}$

Born as Nasuriddin Ebul Hakayık Mahmud Akhi Evran bin Ahmet al Hoyri in Hoy, a city in Western Azerbaijan, Akhi Evran journey to Anatolia started with a visit to Kayseri after his pilgrimage, and then to Konya with his father-inlaw and Muhiddin Ibn al-Arabi via Baghdad. In spreading the ideas of Futuwwa to the Anatolian region, Akhi Evran's father-in-law Evhadü'd Din Hamid alKirmani journey to Anatolia was to assume the post as the Sheikh of Anatolia (Sehhü'ş-şuyuhi'r Rum). ${ }^{5}$ With his primary profession as a tanner, 6 Akhi Evran was so much loved and respected as a professional and chosen to leader 32 different occupational groups. He visited many cities in Anatolia and set the foundation for intellectual development under his leadership (1171-1261) in Anatolia. ${ }^{7}$

\footnotetext{
${ }^{4}$ Hatice Çubukçu, "Bâciyân-ı Rûm ve Anadolu Tasavvufundaki Yeri," FSM İlmî Araștırmalar Insan ve Toplum Bilimleri Dergisi 5, no. 5 (June 30, 2015): 217-29, https://doi.org/10.16947/ fsmiad.88751.

5Umut Güner, Tarihte Fütüvvet ve Ahilik. Siyasi, Dini ve Sosyal Yönleriyle (İstanbul: Ötüken Neşriyat A.Ş, 2017).

${ }^{6}$ Ebubekir Aytekin, Tarihten Gunumuze Futuvvet ve Ahilik (Istanbul: Kayihan Yayinlari, 2017).

${ }^{7}$ Arif Hüdai Köken and Nüket Örnek Büken, "XIII. Yüzylla Güçlü Bir Toplumun Gelişmesine Katkı Sunan Fatma Bacı ve Dünyanın İlk Kadın Örgütlerinden: Bacıyân-ı Rûm (Anadolu Bacılar
} 
Besides, his efforts gave birth to establishing the Akhi organization that served as a professional organization regulating occupational rules and provided vocational training. It also endeavored to train the "Ideal Person," a principle guided by well manners and generosity by the virtues of Futuwwa. They therefore attached importance to women and girls' education and social life and included them in every aspect of social life. As the Akhi men began to feel the need for the help of women, these women and sisters started to operate commercially and socially along with their husbands after undergoing Sufi and moral education. ${ }^{8}$

Suddenly, the sisters started to take charge of their own Sufi and moral education as they are provided with occupational training to function as men. These developments formed one of the essential elements of the Baclyan-l Rum Organization, which was established and institutionalized according to the understanding of the Turkish-Islamic Civilization, to gain "Rızayı Ilahi" (the Divine Consent) and to maintain and preserve human lives by following this principle and preserving it to the next generations. ${ }^{9}$ Thus, education was seen as a whole pack that consists of experience, materials, and morals, and anybody who received such education was not left out even after completing the education process, as there were constant supervision and control. This system became a blueprint for people and artisan's self-control. It also served as a socially responsible work ethics and control mechanism among the traders and themselves..$^{10}$

Nonetheless, historical sources, especially the famous Ottoman historian Aşık Paşazade, ${ }^{11}$ classified the immigrant Turkmen communities from Central Asia into Akhis, Abdals, Veterans, and Sisters. Later in the 14th century, the Moroccan scholar and world-traveler of the Middle Ages Ibn Battuta (13041368) was one of the few travelers who traveled to distant places and stayed

Teşkilat)," Mersin Üniversitesi Tıp Fakültesi Lokman Hekim Tip Tarihi ve Folklorik Tip Dergisi 8, no. 2 (May 30, 2018): 111-17, https://doi.org/10.31020/mutftd.418492.

'Sefa Bulut, "Ahi Women's: The First Women's Non-Governmental Organization in the World," Sociology Insights 4, no. 1 (2020): 1-4.

${ }^{9}$ Ömür Toker and Halil Özdemir, "Yüksek Sosyabilite Sahibi Türk İslam Medeniyeti Kadın Modeli 'Bacıyan-ı Rum,'” in IV. Uluslararasi Türk Dünyasi Araştirmalari Sempozyumu, vol. 4 (Niğde, 2017), 705-14.

${ }^{10}$ Bulut, "Ahi Women's: The First Women's Non-Governmental Organization in the World."

${ }^{11}$ Așlk Paşazade and Derviş Ahmed Așiki, Osmanoğullarının Tarihi: Tevarih-i Al-i Osman (İstanbul: Gökkubbe, 2007). 
there a long time. He is believed to have set off from the city of Tangier in North Africa and traveled around the world. After making his third pilgrimage to Mecca, he decided to continue his travels. This time to Anatolia, from which he will connect with the Turkish caravans to India. He came to Alanya from the port of Latakia in Syria on a Genoese galley in 1333 and was full of praise about the people of Anatolia. He reported that the Turkmen lived there and other Egyptian and Syrian merchants. ${ }^{12}$

During his detailed visit to Anatolia, the famous traveler stayed in the Akhi lodge and zawiya in the villages, towns, and cities. Zawiyas were small dervish lodges with adjacent places of worship and shelter. In his words, these zawiyas were even in small places in every city he visited, and guests were received there. He also stated that these zawiyas had economic, religious, social, and educational functions and he preferred to stay mainly in those places. ${ }^{13}$ The famous traveler also appreciated the Akhi women who welcomed guests into the zawiyas with their exceptional hospitality skills. These observations and praise reflect the importance of women and women organizations of that period.

Furthermore, Ibn Battuta also noticed many anthropological elements about the daily and routine lives of the Akhis. He reported that the Akhis (brothers) was formed by single men who went to work in the morning, returned and gave the money they earned to their Akhi president, stayed in the zawiyas, and received vocational and Sufi education. This embodiment is what is called "futuwwa" (youth). A retreat to promote ethics and pursue inward and outward manly discipline. Younger people who also engage in such ethical principles and pursuits are called "fityan" (youngsters). Moreover, this Akhis ethics and principles were said not to be limited to single and unmarried men, as married men were also allowed and encouraged to adopt such inward and outward manly discipline.

Besides such brotherhood, a women's branch was also in existence. ${ }^{14} \mathrm{Ibn}$ Battuta praised and admired the fact that Akhi women made food and

\footnotetext{
${ }^{12}$ Mesut Atasever, "Ahi Organizations in Terms of Corporations, Corporation Associates and Business Ethics in Anatolia of the Middle Ages: An Analysis of the Ibn Battuta's Travelogue," Journal of Multidisciplinary Development 2, no. 1 (2017): 33-40.

${ }^{13}$ Atasever.

${ }^{14}$ Çubukçu, "Bâciyân-ı Rûm ve Anadolu Tasavvufundaki Yeri.”
} 
provisions for guests. This, to him, was one reason he wanted to stay in the Akhi zawiyas. He further argued that he had not seen anyone as virtuous and moral as the Akhis. ${ }^{15}$ Notwithstanding their hard work, they were also motivated by the idea of altruism, helping the poor, lonely, and elderly. 16 These processes evolved until the establishment of an industrial site for the Akhis and the Sisters by Seljuk Sultan Kaykhusraw I with the support of the state as part of the restructuring activities of the Seljuk state in Kayseri.

Later, during Sultan Ala ad-Din Kayqubad, they spread throughout Anatolia and took a pivotal part in the state structure. Indeed, in these periods, Akhi women and men were in charge of the municipal and police affairs of the cities. ${ }^{17}$ This suggests that the Baclyan-l Rum women's organization and the Akhi organization are the two medieval organizations that were established at the same time. Even though they were parallel to each other, they also supported and complemented each other. These two organizations spread to the most distant and far-flung corners of Anatolia quickly, which led to the tremendous economic and cultural vitality and development. These developments continued until the Mongol invasion. Unfortunately, the Mongol attacks did not only cause tremendous harm to all the people of Anatolian and mainly targeted the Akhi women and men who resisted them. These Mongolians were notorious for their extreme cruelty in places they occupied and resisting any form of occupation. The Turkmens moved from Eastern Turkic Central Asia, Mavera'ül nehir, and Khorasan because of the Mongolians invasions.

Despite the invasion, the Akhi men and women organizations stood firm to defend their land and beliefs. This resulted in them facing extreme torture and all kinds of violations from the hands of Mongols in Anatolia. The Turkic tribes were not barbaric or uncivilized, unlike what has been said in western publications. When they arrived in Anatolia, they had good neighboring relations with the Greeks and Armenians, which continued until the 20th century. ${ }^{18}$ In fleeing from the Mongol attacks, Central Asians and Khorasan

\footnotetext{
15İsmet Parmaksızoğlu, İbn Battuta, Seyahatnâme (Ankara: Milli Eğitim Bakanlığı Yayınları, 1971).

16Bulut, “Ahi Women's: The First Women's Non-Governmental Organization in the World.”

${ }^{17}$ Mikail Bayram, Bacıyanı-ı Rum (Anadolu Bacılar) ve Fatma Bacı, Türkler (Ankara: Yeni Türkiye Yayınlan, 2002).

18Bulut, "Women's Social Status and Prestige in Asia Minor during Medieval Era."
} 
Turks also come to Anatolia. This marked the Turkification and Islamization of the Anatolian region, as it was a period of mass migration that involved tradespeople, merchants, farmers, herbalists, scholars, professors, and Sufis, among others. This led to a vast intellectual Renaissance in Anatolia and formed the structure and foundation for Turkish and Ottoman history development.

Afterward, Akhi Evran founded the Ahiyan-ı Rum Organization (Anatolian Akhi Organization). This was a male branch to his wife Fatma Hatun (Fatma Bacl) Baclyan-ı Rum Organization (Anatolian Sisters; Anatolia was known as the land of Rum back then), which is the first women's non-governmental organization in history, made up of Akhi women and young girls. Fatma Bacl is often regarded as an essential personality in the history of Baclyan-l Rum Organization. Notwithstanding her efforts and devotion to the education and training of girls and women, she also received tremendous support from both her father, Sheikh Kirmani, and her husband Akhi Evran for the education and training of girls and women. Her father made sure his daughters received a good education that comprises vocational and intellectual training. ${ }^{19}$ Even though she was said to be naughty while growing up as a child, her father had to receive training in being patient. ${ }^{20}$ Also, her mother, Amine Hatun, being an educated woman, took particular interest in catering and caring for her daughters. She educated and taught them knitting and weaving along with their other forms of education. This again shows the importance given to women during that period as they were given their place in the business of life.21 All these cultural transfers and transformations such as art education, character, and regular daily education she received from her parents became the basic philosophy and purpose of Baclyan-ı Rum women's organization and lived for generations. $^{22}$

Therefore, it is evident that the foundation of the Bacıyan-ı Rum women's organization originated not only due to cultural reasons but from the challenges

\footnotetext{
${ }^{19}$ Necati Gültepe, Türk Kadın Tarihine Giriş- Amazonlardan Bacıyan-ı Rumdan Günümüze Türk Kadınının İktisadi Hayattaki Yeri (İstanbul: İstanbul Ticaret Odası, 2008).

${ }^{20}$ Mikail Bayram, "Anadolu Selçukluları Devrinde Anadolu Bacıları (Baclyan-ı Rum) Teșkilat'nın Kurucusu Fatma Bacı Kimdir?," SEFAD - Selçuk Üniversitesi Edebiyat Fakültesi Dergisi, no. 1 (1981): 57-72.

${ }^{21}$ Mikail Bayram, Fatma Bacı ve Bacıyanı-ı Rum (Anadolu Bacılar Teșkilatı) (Konya: Çizgi Kitabevi, 2016).

22Bayram, Baclyanı-ı Rum (Anadolu Bacllar) ve Fatma Bacı, Türkler.
} 
experienced by the Turkmen who had come to Anatolia. The emergence of this women's organization in Kayseri at that time was because Kayseri was also a geographically, commercially, and scientifically important city. ${ }^{23}$

Another reason why the Akhis migrated to other regions was also due to a rebellion termed as Babailer in Anatolia in 1240; thus, many Akhis and Turkmens were monitored and tortured. Thus, the Akhis in the central regions were forced to migrate to Ankara and elsewhere. Later in 1243, when the Mongols finally defeated the Seljuks in the Battle of Kösedağ, the remaining Akhis and Sisters had to also migrate to Ankara and other regions. ${ }^{24}$ This led to the culture and traditions of this organization moving to other places. Later on, when the Seljuks withdrew from the administration of Ankara in 1330, the Akhis assumed both the defense and the municipal services of the city and provided public order for a long time. They elected ruling leaders, sheikhs, and chamberlains within themselves through democratic methods. This period lasted for 31 years until 1361, when the Ottomans took Ankara. The Akhis later settled in an area called Bentderesi in Ankara and established tanneries along the creek. Women also worked in weaving and knitting workshops, and they lived with their families in the houses behind the shops where they worked.

Regardless of this development, the Akhis built and maintained highly developed architectural structures in the areas they lived; for example, there were water cisterns, cellars, and pools. In those places, leathers were tanned and made ready for use. The goods produced were of a wide variety and colors; they produced men and women boots, shoes, and leather clothes. It was also a period when Turkish clothes were very famous and were the favorites of Western, Egyptian, and Syrian merchants. Moreover, it was also a period where other products like bridle, drawgears, saddles, and belts were manufactured for horses and sold in bazaars called a rasta. The Angora goat, known as the Ankara goat, was also brought from Tibet to Anatolia by the Turkmen, which later led to the production of Angora wool, which played a significant part in developing the economy.

\footnotetext{
${ }^{23}$ Mikail Bayram, Fatma Bacı ve Bacıyan'ı Rum (Istanbul: Nüve Kültür Merkezi Yayınları, 2008).

${ }^{24}$ Mehmet Ali Hacıgökmen, “Ankara Ahilerin Ticari Faaliyetleri ve Bacıyan-ı Rum Hakkında Bir Araştırma," Ankara Üniversitesi Osmanlı Tarihi Araștırma ve Uygulama Merkezi Dergisi 18 (2005): 185-212.
} 


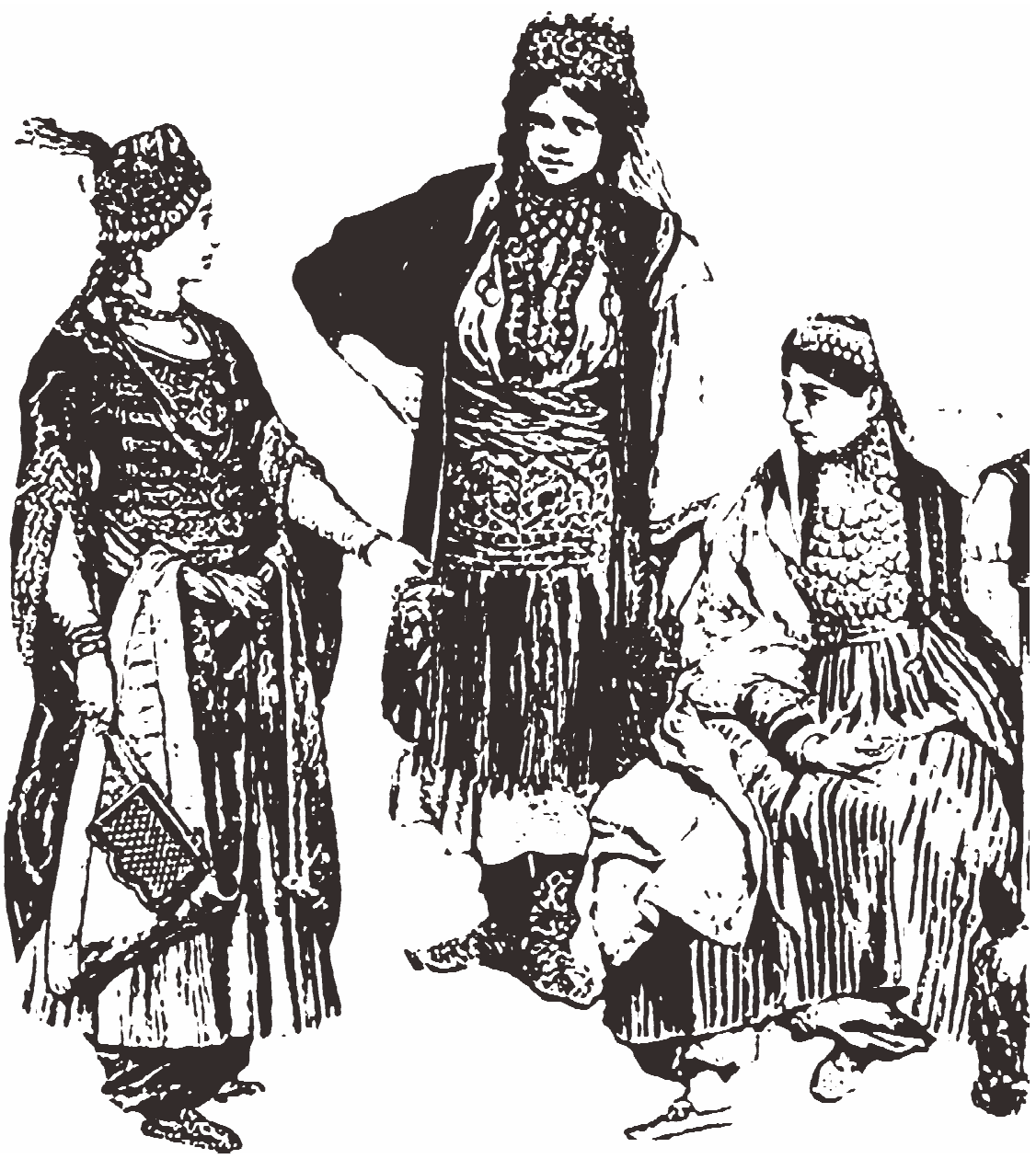

Figure 1

Illustration of Baclyan-I Rum women ${ }^{25}$

By the 14th century, Sisters living in Ankara and its villages were spinning Angora wool to make threads sell them in sure bazaars. ${ }^{26}$ Several foreign

25Picture is taken from the book cover image, Bayram, Fatma Bacl ve Bacıyanı-1 Rum (Anadolu Bacılar Teșkilatı); See; “Dünyanın Bilinen En Eski Kadın Teșkilatı: Bâcıyân-ı Rûm,” fikriyat.com, 2018, https://www.fikriyat.com/kultur-sanat/2018/02/19/dunyanin-bilinen-en-eski-kadin-teskilatibciyn-i-rm. 
travelers and envoys also provided information about textile weaving and Angora wool production in Ankara. Till today there is a district called Bacr and a village called Fatma Bacı in Ankara. There are also sisters titled Akhi, and these women establish foundations in Ankara. Going by the original doctrine of the Akhism, there are still properties and wealth of these women in Ankara to be used freely. Because Akhism is a profession of generosity and feeding others, seeing and holding others superior to oneself, Sisters also spent all their earnings to benefit people and the foundations.

Notably, one of the most well-known characteristics of the Akhi women is their welcoming nature, particularly guests coming to the lodges and zawiyas. Perhaps the well-known traditional Turkish hospitality dates back to this period. Also, the Turkmen tribes were immigrants coming to Anatolia from the far east; so, it was necessary to host and take care of other new guests. They had to accommodate newcomers and help them adapt to the new environment, and these Akhi women fulfilled this task nicely whenever needed. ${ }^{27}$ Ibn Battuta also had positive attributes to say regarding these women. To him, Akhi women are very welcoming, and they offered great treats wherever they had been. In his practical experience, they welcomed him very well, prepared previsions for him, and cheerfully said goodbye to him. The famous traveler did not only speak highly of them in terms of their hospitality, but in his words, he said he had never seen such beautiful hospitality anywhere else, and the Anatolian people are the most beautiful, cleanest, best cookers and the most compassionate people he had ever seen. Above all, he spoke about Allah's blessings and said He granted different blessings to different countries but gave all forms of blessing to Anatolia. This was sole because he was touched by the abundance of different varieties of food and the fertility nature of the country. ${ }^{28}$

Even though at present, the lodges and the zawiyas were built by the Turkmen to receive visitors, and for vocational training, it later contributed to the Islamization and Turkification of Anatolia. The female dervishes in these lodges sometimes went to the frontiers and conducted conquest and guidance in the border regions together with the armies. It was also a period in the Seljuk

\footnotetext{
${ }^{26}$ Hacıgökmen, “Ankara Ahilerin Ticari Faaliyetleri ve Bacıyan-ı Rum Hakkında Bir Araştırma.”

${ }^{27}$ Bayram, Fatma Bacı ve Baclyan'ı Rum.

${ }^{28}$ Çakmakçi Cevdet, "İbn Battûta Seyâhatnâmesi'nde Türkçe Kelimeler," Ankara Üniversitesi İlahiyat Fakültesi Dergisi 47, no. 1 (2006): 159-98, https://doi.org/10.1501/Ilhfak_0000000041.
} 
and Ottoman era that recorded women zawiya sheikhs called hatuns. ${ }^{29}$ These women who received religious and Sufi education in a multidisciplinary dimension set the blueprint for other Anatolia habitats, especially the Greeks, due to their excellent morals and pioneers in accepting Islam. ${ }^{30}$ By and large, the women from Baclyan-1 Rum were raised with powerful religious and national mentality. Thus, they established relations with non-Muslim women, engaged in tablighi (spreading the faith) activities, and led them to Islamization. ${ }^{31}$

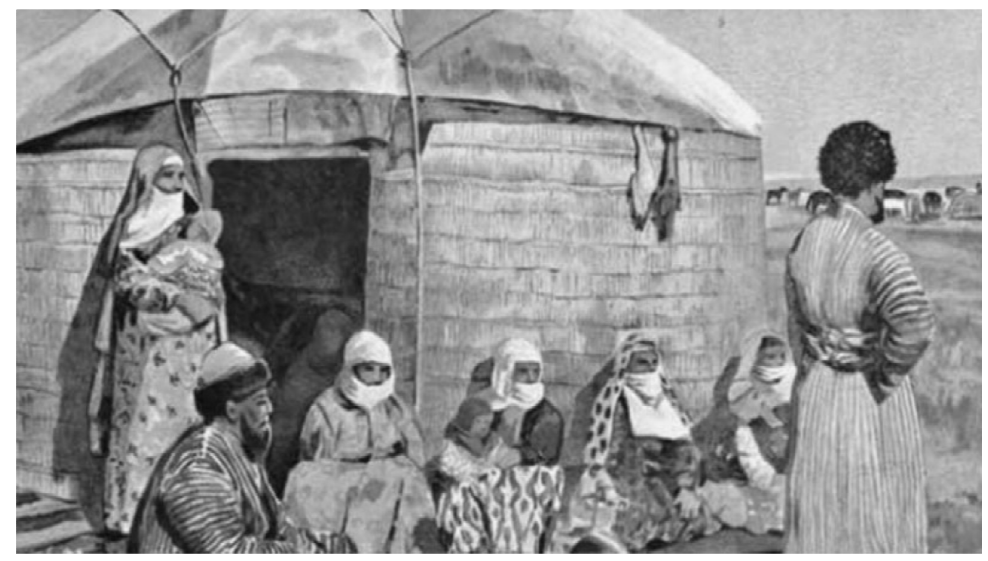

Figure 2

Illustration of Bacıyan-ı Rum women 32

Just as Haji Bektash Veli spoke highly about the contribution of Akhi Evran contribution to the initial course of Akhism and Futuwwa, he also outlined and spoke highly of Fatma Bacı in his book "Vilayetname" and described her as "a miracle worker, a knowledgeable mentor" and referred to her as "Kadıncık Ana" ("Head of Mothers"). Other historians and folklorists also believed that

\footnotetext{
${ }^{29}$ Ömer Lütfi Barkan, "İstila Devirlerinin Kolonizatör Türk Dervișleri ve Zaviyeler," Insan ve Ínsan 2, no. 5 (2015): 5-37.

${ }^{30}$ Yasemin Tümer Erdem and Halime Yiğit, Bacıyan-ı Rum'dan Günümüze Türk Kadınlarının İktisadi Hayattaki Yeri (Istanbul: İstanbul Ticaret Odası, 2010).

31Toker and Özdemir, "Yüksek Sosyabilite Sahibi Türk İslam Medeniyeti Kadın Modeli 'Bacıyan-ı Rum."'

32“Dünyanın Bilinen En Eski Kadın Teşkilat: Bâcıyân-ı Rûm.”
} 
Haji Bektash Veli adopted Fatma Hatun. Just as the Sisters were generally said to be from the Evhadiyye sect, they were also mentors and sheikhs. ${ }^{33}$ Haji Bektash Veli, the founder and leader of the Bektashi Order in his work Vilayetname, Fatma Bacl was reported to have been given spiritual authority, and she saw to it that his grave was built after his death. Fatma Bacl was a woman respected by the saints and the dervishes and was regarded as the mother of the saints, with Abdal Musa among her disciples.

Among her contributions and devotions, she was often regarded as the person who heralded the arrival of Haji Bektash Veli to Anatolia. ${ }^{34}$ In Vilayetname, when Haji Bektash Veli came to Sulucakaraöyük, Fatma Bacı was in a conversation in the Assembly of the Saints. In this assembly, some thought she had a higher social position than men. ${ }^{35}$ During the foundation of the Ottoman State, her women's organization also produced the uniforms that the Janissaries wore. These Janissary soldiers were subject to the ruling of the Bektashi Order, and they went through religious and Sufi education. Later as the foundation of the Ottoman State grew, the Baclyan-ı Rum Organization continued spreading their religious and Sufi education in lodges. ${ }^{36}$

Finally, this first women's organization continued to play essential functions in the history of Anatolia until the establishment of institutions in the Ottoman State in the 15th century. In light of that, the Akhi and Sisters organizations were no longer needed, as new state institutions were created to fulfill their functions. Thus, the Akhis, Abdals, and Sisters became part and parcel of the Bektashi Order and gradually disappeared from the pages of history. However, the Baclyan-ı Rum women made significant contributions to the Islamization of Anatolia and the Balkans, coupled with the foundation of the Ottoman state. This was solely one of the powers that enabled the rise of the Seljuks, and later the Ottoman State was more of Turkmen women with mature personalities who were raised in the Bactyan-ı Rum Organization to be effective care about social, spiritual, and humanitarian values.

\footnotetext{
33BBayram, Fatma Bacı ve Bacıyan'ı Rum.

${ }^{34}$ Bayram, “Anadolu Selçukluları Devrinde Anadolu Bacıları (Bacıyan-ı Rum) Teșkilatı'nın Kurucusu Fatma Bacı Kimdir?”

350kan Nimet, "Alevilikte Kadın Erkek Eșitliği Söylemine Eleștirel Bir Yaklașım," Antropoloji Dergisi 28, no. 28 (2014): 27-40, https://doi.org/10.1501/antro_0000000301.

36Döğüș, "Kadın Alplardan Bacıyanı-ı Rum’a (Anadolu Bacıları Teşkilatı); Türklerde Kadının Siyasi ve Sosyal Mevkii."
} 
Unlike many other ancient cultures where women were seen as creatures second to men, or more specifically as unhappy vices to men, the Anatolians had a more rational approach. Regardless of gender, all humanity was given equal opportunities to be productive within families and the wider community. Based on the above insightful explorations of facts and findings, it is reflective to propose that Akhi Women within the Bacl-1 Rum organization had a limitless role in public life. These women in ancient Anatolia initiated educational and productive activities, which turn out to be core elements of social and moral movement across Anatolia. It is also understood that they prepared women and sisters by empowering and providing them with skills at various stages of life to contribute to community service and actively took part in military defense services when necessary.

Therefore, throughout the history of Anatolia or the Akhi Turkmen, women have always been on top of essential stages as trade and productive laborers, sovereign supremacies, teachers, nationalists, and notably as household managers. We do not also forget them been well respected among men and icons able to carry significant responsibilities on their broad shoulders.

\section{Conclusion}

To conclude, this study's main area turns to emphasize and account is that people and societies have much to learn from the Bacl-1 Rum organization, Akhism order, doctrine, and women's position and contribution in ancient Anatolia.

Social sciences are developing very fast, and gender studies are becoming very popular in psychology, sociology, and anthropology. The current study gives some glips about historical perspectives about men's and women's lives and how they worked and evolved together. It would not be an exaggeration to say that similar organizations may flourish in another part of the world; therefore, the researcher should investigate other cultures to look for similar phenomena.

This could be a starter for the researchers to pay attention to historical events and occurrences that can bring about much new knowledge that has never been attempted to unearth and become the research topic.

Another way of approaching scientific research could be an interdisciplinary approach. Because when we are doing social research, it is really to find any events with only one reason or one result. We have to take into 
consideration many things and consider many variables. Hence, it is essential to have a global and interdisciplinary approach to investigate the relevant information. Then, this will lead us to believe that it is the researcher's responsibility to locate the accurate information, do the necessary clarification and confirmation and act ethically to analyze and synthesize the available resources to reach accurate and true knowledge.[s]

\section{References}

Atasever, Mesut. "Ahi Organizations in Terms of Corporations, Corporation Associates and Business Ethics in Anatolia of the Middle Ages: An Analysis of the Ibn Battuta's Travelogue." Journal of Multidisciplinary Development 2, no. 1 (2017): 33-40.

Aytekin, Ebubekir. Tarihten Gunumuze Futuvvet ve Ahilik. Istanbul: Kayihan Yayinlari, 2017.

Barkan, Ömer Lütfi. “İstila Devirlerinin Kolonizatör Türk Dervişleri ve Zaviyeler.” İnsan ve Insan 2, no. 5 (2015): 5-37.

Bayram, Mikail. "Anadolu Selçukluları Devrinde Anadolu Bacıları (Bacıyan-ı Rum) Teşkilatı'nın Kurucusu Fatma Bacı Kimdir?" SEFAD - Selçuk Üniversitesi Edebiyat Fakültesi Dergisi, no. 1 (1981): 57-72.

Bacıyanı- Rum (Anadolu Bacılar) ve Fatma Bacı, Türkler. Ankara: Yeni Türkiye Yayınları, 2002.

—__ Fatma Bacı ve Bacıyan'ı Rum. Istanbul: Nüve Kültür Merkezi Yayınları, 2008.

___ Fatma Bacı ve Bacıyanı-ı Rum (Anadolu Bacılar Teșkilatı). Konya: Çizgi Kitabevi, 2016.

Bulut, Sefa. “Ahi Women's: The First Women's Non-Governmental Organization in the World." Sociology Insights 4, no. 1 (2020): 1-4.

___. "Women's Social Status and Prestige in Asia Minor during Medieval Era." Sociology Insights 3, no. 1 (2019): 1-2.

Cevdet, Çakmakçi. "İbn Battûta Seyâhatnâmesi'nde Türkçe Kelimeler." Ankara Üniversitesi İlahiyat Fakültesi Dergisi 47, no. 1 (2006): 159-98. https://doi.org/ 10.1501/Ilhfak_0000000041.

Çubukçu, Hatice. "Bâciyân-ı Rûm ve Anadolu Tasavvufundaki Yeri." FSM İlmî Araştırmalar İnsan ve Toplum Bilimleri Dergisi 5, no. 5 (June 30, 2015): 217-29. https://doi.org/10.16947/fsmiad.88751.

Döğüș, Selahattin. "Kadın Alplardan Bacıyanı-ı Rum'a (Anadolu Bacıları Teşkilatı); Türklerde Kadının Siyasi ve Sosyal Mevkii." Kahramanmaraş Sütçü İmam Üniversitesi Sosyal Bilimler Dergisi 12, no. 1 (2015): 127-50. 
fikriyat.com. "Dünyanın Bilinen En Eski Kadın Teşkilatı: Bâcıyân-ı Rûm," 2018. https://www.fikriyat.com/kultur-sanat/2018/02/19/dunyanin-bilinen-eneski-kadin-teskilati-bciyn-i-rm.

Erdem, Yasemin Tümer, and Halime Yiğit. Baclyan-ı Rum'dan Günümüze Türk Kadınlarının Iktisadi Hayattaki Yeri. Istanbul: İstanbul Ticaret Odası, 2010.

Gültepe, Necati. Türk Kadın Tarihine Giriş- Amazonlardan Bacıyan-ı Rumdan Günümüze Türk Kadınının İktisadi Hayattaki Yeri. İstanbul: İstanbul Ticaret Odasl, 2008.

Güner, Umut. Tarihte Fütüvvet ve Ahilik. Siyasi, Dini ve Sosyal Yönleriyle. İstanbul: Ötüken Neşriyat A.Ş, 2017.

Hacıgökmen, Mehmet Ali. "Ankara Ahilerin Ticari Faaliyetleri ve Bacıyan-ı Rum Hakkında Bir Araștırma." Ankara Üniversitesi Osmanlı Tarihi Araştırma ve Uygulama Merkezi Dergisi 18 (2005): 185-212.

Kazıcı, Ziya. "Esnaf Teşkilatı Ahilik." Diyanet Dergisi 17, no. 3 (1978): 250-56.

Köken, Arif Hüdai, and Nüket Örnek Büken. "XIII. Yüzyllda Güçlü Bir Toplumun Gelișmesine Katkı Sunan Fatma Bacı ve Dünyanın İlk Kadın Örgütlerinden: Bacıyân-ı Rûm (Anadolu Bacllar Teșkilatı)." Mersin Üniversitesi Tıp Fakültesi Lokman Hekim Tip Tarihi ve Folklorik Tip Dergisi 8, no. 2 (May 30, 2018): 11117. https://doi.org/10.31020/mutttd.418492.

Nimet, Okan. "Alevilikte Kadın Erkek Eșitliği Söylemine Eleştirel Bir Yaklaşım." Antropoloji Dergisi 28, no. 28 (2014): 27-40. https://doi.org/10.1501/ antro_0000000301.

Parmaksızoğlu, İsmet. İbn Battuta, Seyahatnâme. Ankara: Milli Eğitim Bakanlı̆̆ Yayınları, 1971.

Paşazade, Așık, and Derviș Ahmed Așıki. Osmanoğullarının Tarihi: Tevarih-i Al-i Osman. İstanbul: Gökkubbe, 2007.

Toker, Ömür, and Halil Özdemir. "Yüksek Sosyabilite Sahibi Türk İslam Medeniyeti Kadın Modeli 'Bacıyan-ı Rum.'” In IV. Uluslararasi Türk Dünyasi Araștirmalari Sempozyumu, 4:705-14. Niğde, 2017. 